\title{
KAJIAN KARAKTERISTIK DIGESTER KOTORAN SAPI BERDASARKAN KOMPOSISI AIR BERBASIS KINETIKA GAS METANA UNTUK PRODUKSI GAS BIO
}

\author{
Characteristic Study of Cow Dung Digester Based on Water Composition and Kinetics of Methane \\ Gas for Biogas Production
}

\author{
Mu'anah $^{1}$, Cahyawan Catur Edi Margana ${ }^{1}$, Asih Priyati $\left.{ }^{1, *}\right)$ \\ ${ }^{1}$ Program Studi Teknik Pertanian Fakultas Teknologi Pangan dan Agroindustri \\ Universitas Mataram \\ Email $^{*}$ : r_yuhaeri@yahoo.com
}

Diterima: 2 Desember 2017

Disetujui: 13 Februari 2017

\begin{abstract}
Biogas is one renewable energy that could be used as an alternative energy. In accordance to the increasing energy demand, cow dung could be used as source to produce biogas as fuel or bioslurry. Biogas is produced through fermentation process, where methan $\left(\mathrm{CH}_{4}\right)$ gas is the main product. This research aims were to designed and constructed cow dung digester and to understand the methan gas production. The fermentation process was conducted by anaerobic using microbacteria. This research was conducted using experimental method by applying randomized block design based on laboratorium and on field experiments. Three treatments were used in this experiment, i.e., 1:1, 1:2, and 2:1 using three replication with observed parameter of temperature, pressure, production rate, and density of methan gas. Observation was done in 2 days respectively at $0,12,24,36$, and 48 hours. Total unit treated in this experiment was 18 units. In the field experiment, result showed that methan production rate based on theoritical approach (stoichiometry) and experimental was consistent on 2:1 treatment with average \%ERMS $<10 \%$ (valid), which indicated that the stoichiometry existed on diluted phase. For kinetics approach, the equation for $1: 1,1: 2$, and $2: 1$ ratio could be determined respectively as $y=-0.74 x-0.238 \quad\left(R^{2}=\right.$ $0.772), y=-0.014 x+0.238\left(R^{2}=0.772\right)$, and $y=-0.112 x-1.023\left(R^{2}=0.723\right)$.
\end{abstract}

Keywords: digester, methan $\left(\mathrm{CH}_{4}\right)$ gas, cow dung

\begin{abstract}
ABSTRAK
Biogas adalah salah satu energi terbarukan yang dapat digunakan sebagai energi alternatif. Seiring dengan meningkatnya kebutuhan energi limbah (kotoran sapi) dapat dimanfaatkan sebagai salah satu bahan pembuatan biogas, baik sebagai bahan bakar maupun bioslurry. Proses pembuatan biogas melalui proses fermentasi yang menghasilkan gas metana $\left(\mathrm{CH}_{4}\right)$ sebagai produk utama. Tujuan penelitian ini adalah untuk mempelajari desain dan konstruksi alat digester serta mengetahui secara ilmiah proses produksi gas metana. Proses fermentasi dilakukan secara anaerobik oleh mikrobia. Penelitian ini dilakukan dengan menggunakan metode eksperimental, menggunakan Rancangan Acak Kelompok (RAK) berdasarkan percobaan di laboratorium dan di lapangan dengan 3 (tiga) perlakuan (air : kotoran), yakni perlakuan 1:1, 1:2, dan 2:1 diulang 3 (tiga) kali, kemudian diukur parameter-parameter penelitian: suhu, tekanan gas, laju produksi gas metana $\left(\mathrm{CH}_{4}\right)$ dan massa jenis. Pengamatan dilaksanakan selama 2 hari, yakni pada jam berturutturut $0,12,24,36$, dan 48 jam. Total unit percobaan sebanyak 18 unit. Pada percobaan di lapangan diperoleh hasil analisis laju produksi gas metana antara pendekatan teoritis (stoikiometri) dengan eksperimental diperoleh kesesuaian pada perlakuan sampel 2:1 dengan nilai rata-rata \% ERMS < $10 \%$ (valid) dengan kata lain menunjukkan bahwa persamaan stoikiometri berlaku untuk kondisi perlakuan encer. Lebih jauh pada aspek kinetika, dalam penentuan konstanta produksi gas metana
\end{abstract}


kesemua perlakuan untuk perbandingan $1: 1,1: 2$, dan $2: 1$ berturut-turut $\mathrm{y}=-0.74 \mathrm{x}-0.238\left(\mathrm{R}^{2}=\right.$ $0.772) ; y=-0.014 x+0.238\left(R^{2}=0.772\right) ; y=-0.112 x-1.023\left(R^{2}=0.723\right)$.

Kata kunci: digester, gas metana $\left(\mathrm{CH}_{4}\right)$, kotoran sapi

\section{PENDAHULUAN}

Bahan bakar minyak merupakan energi fosil tertua yang tidak dapat diperbaharui menyebabkan ketersediaan di dalam bumi secara cepat maupun lambat akan semakin menipis. Hal ini disebabkan setiap gerak dan aktifitas kehidupan manusia mulai dari yang paling ringan selalu membutuhkan energi sehingga penggunaan energi semakin meningkat (Marsono, 2008).

Pemanfaatan limbah peternakan (kotoran sapi) merupakan salah satu alternatif yang sangat tepat untuk mengatasi naiknya harga pupuk dan kelangkaan bahan bakar minyak, terutama pemanfaatan kotoran ternak sapi sebagai sumber bahan bakar dalam bentuk biogas. Teknologi dan produk tersebut merupakan hal baru bagi masyarakat petani dan para peternak. Pemanfaatan kotoran ternak sebagai sumber energi tidak mengurangi jumlah pupuk organik yang bersumber dari kotoran ternak. Hal ini karena pada pembuatan biogas kotoran ternak yang sudah diproses dikembalikan ke kondisi semula yang diambil hanya gas metana $\left(\mathrm{CH}_{4}\right)$ yang digunakan sebagai bahan bakar (Rahayu, 2008).

Biogas merupakan salah satu dari banyak macam sumber energi terbarukan, karena energi biogas dapat diperoleh dari air buangan rumah tangga, kotoran cair dari peternakan ayam, sapi, babi, sampah organik dari pasar, industri makanan dan limbah buangan lainnya. Produksi biogas memungkinkan pertanian berkelanjutan dengan sistem proses terbarukan dan ramah lingkungan. Pada umumnya, biogas terdiri atas gas metana $\left(\mathrm{CH}_{4}\right)$ sekitar $55-80 \%$ yang diproduksi dari kotoran hewan yang mengandung energi 4800-6700 Kcal $/ \mathrm{m}^{3}$, sedangkan gas metana murni mengandung energi $8900 \mathrm{Kcal} / \mathrm{m}^{3}$. Sistem produksi biogas mempunyai beberapa keuntungan seperti mengurangi pengaruh gas rumah kaca, mengurangi polusi bau yang tidak sedap, sebagai pupuk dan produksi daya dan panas (Wahyuni, 2009).

Berdasarkan uraian di atas dan untuk mengetahui bagaimana proses produksi selama fermentasi kotoran sapi di dalam digester baik di lapangan dan laboratorium serta untuk mengetahui tekanan yang dihasilkan, maka perlu dilakukan penelitian tentang kajian karakteristik digester kotoran sapi berdasarkan komposisi air berbasis kinetika gas metana untuk produksi gas bio.

\section{Tujuan Penelitian}

1. Mempelajari sistem kerja instalasi alat pembuatan biogas dari kotoran sapi.

2. Mengetahui laju produksi gas metana yang dihasilkan dengan komposisi air yang berbeda skala laboratorium dan lapangan.

3. Mengetahui perlakuan terbaik berdasarkan analisis aktual dan stoikimetri.

4. Mengetahui secara ilmiah proses produksi gas bio.

\section{METODE PENELITIAN}

\section{Waktu Penelitian}

Penelitian ini dilaksanakan selama 2 bulan yaitu pada bulan Maret sampai April 2014.

\section{Tempat Penelitian}

Penelitian ini dilaksanakan di Laboratorium Daya dan Mesin Pertanian dan Teknik Bioproses, Fakultas Teknologi Pangan dan Agroindustri Universitas Mataram dan di Lapangan bertempat di Dusun Rean, Kecamatan Gerung, Kabupaten Lombok Barat.
Alat dan Bahan
Alat-alat penelitian
Alat yang digunakan dalam penelitian ini sebagai berikut:
1. Peralatan perbengkelan (las listrik, bor listrik, gergaji besi, gerinda, tang, palu, obeng, dan peralatan lain yang mendukung).
2. Gelas ukur $1000 \mathrm{ml}$
3. Termo digital
4. Luxmeter
5. Manometer
6. BOD meter lovibond oxidirect
7. Oven
8. Viscometer 
9. Oxygen meter

10. Timbangan analitik

11. Desikator

12. Stopwatch

13. Cawan

\section{Bahan-bahan penelitian}

Bahan yang digunakan dalam penelitian ini sebagai berikut:

1. Kotoran sapi yang masih segar dan tidak tercampur oleh kotoran lain.

2. Air

3. Bahan-bahan pembuatan rangkaian alat digester (1 buah tabung plastik sebagai outlet, 3 buah tabung kaca sebagai reaktor, kondensat, dan penampung gas), selang, kran air, lem/isolasi, aluminium, paku dan triplek sebagai dudukan.

4. Kertas saring untuk menyaring larutan

5. Aquades untuk mengencerkan larutan

6. Silica gel untuk menyerap panas.

\section{Metodologi Penelitian}

Penelitian ini menggunakan dengan metode eksperimental. Rancangan yang digunakan dalam penelitian ini adalah Rancangan Acak Kelompok (RAK) dengan menggunakan tiga perlakuan dengan masingmasing tiga kali ulangan, yaitu:

1. 1:1, yaitu 1 liter air dengan 1 liter kotoran sapi.

2. 1:2, yaitu 1 liter air dengan 2 liter kotoran sapi.

3. 2:1, yaitu 2 liter air dengan 1 liter kotoran sapi.

Setiap perlakuan akan diulang sebanyak 3 kali ulangan dengan mengambil data setiap 12 jam sekali serta mengukur parameter-parameter yang sudah ditentukan dan total unit percobaan sebanyak 18 unit percobaan.

\section{Prosedur Penelitian}

\section{Prosedur Laboratorium}

1. Dicampur kotoran sapi yang masih segar dengan air pada wadah sampai terbentuk lumpur.

2. Diaduk lumpur yang sudah merata, dimasukkan kedalam tabung reaktor dengan dipastikan tidak dalam keadaan bocor pada setiap tabung untuk menjaga gas yang terbentuk tidak terbuang.

3. Diamati sesuai parameter yang sudah ditentukan.

\section{Prosedur di lapangan}

1. Dicampur kotoran sapi yang masih segar dengan air, diaduk merata sampai terbentuk lumpur pada setiap perlakuan.

2. Dialirkan lumpur ke dalam digester melalui lubang pipa inlet yang langsung terhubung dengan tempat penampungan. Pada pengisian pertama digester terisi penuh sehingga udara yang ada dalam digester terdesak keluar.

3. Dibuang gas yang dihasilkan pada hari pertama selama 10-40 detik di waterdrain (penguras air) sampai berhenti gelembunggelembung karena yang terbentuk adalah karbondioksida $\left(\mathrm{CO}_{2}\right)$. Selanjutnya yang terbentuk adalah gas metana $\left(\mathrm{CH}_{4}\right)$.

4. Diukur gas yang dihasilkan menggunakan manometer pada setiap perlakuan.

\section{Parameter Penelitian \\ Rancang bangun alat digester}

Pada tahap ini merupakan tahap yang paling penting sebagai langkah awal pada penelitian ini. Perancangan masing-masing komponen sudah dipastikan dalam keadaan tidak bocor/rusak serta sambungan antara tabung yang satu dengan tabung yang lain berdasarkan ketentuan yang ada karena kondisi tersebut sangat mempengaruh sistem kerja untuk mendapatkan data yang benar-benar valid.

Komponen alat digester tersebut terdiri dari tabung reaktor dengan ukuran volume 2,5 $\mathrm{ml}$ yang dilengkapi dengan inlet, tabung kondensasi (tempat pemisahan air dengan gas murni), dan tabung penampung gas yang ditempel dengan menggunakan papan sebagai dudukan. Sedangkan di lapangan digester dibuat permanen dengan ukuran $4^{3}$ liter (empat kubik) tipe kubah yang dibuat tertutup dalam tanah dengan prinsip kerja yang sama dengan laboratorium.

Digester tipe ini memiliki volume tetap sehingga produksi gas akan meningkatkan tekanan dalam reaktor (Hozairi, dkk., 2012). Digester ini dilengkapi dengan inlet dan outlet serta pengukuran gasnya langsung menggunakan alat yang disebut manometer berbentuk $\mathrm{U}$ yang terisi air teh, sehingga untuk mengetahui jumlah gas yang dihasilkan dengan mengukur penambahan tinggi tekanan pada manometer. 


\section{Uji fungsional alat}

Sebelum melakukan langkah lebih lanjut, terlebih dahulu dilakukan pengujian alat. Setelah alat tersebut dapat melakukan proses fermentasi dengan baik dan menghasilkan tekanan yang diukur menggunakan luft meter karena menggunakan sampel skala kecil selanjutnya dilakukan pengambilan data. Sedangkan di lapangan untuk pengujian dilakukan dengan pengisisian tabung reaktor terlebih dahulu kemudian ditunggu 2-3 hari sehingga terbentuk gelembung dan ditunggu sampai hilang karena yang dibutuhkan adalah gas metana kemudian dialirkan melalui pipa yang langsung terhubung dengan manometer dan kompor gas sudah bisa menyala dengan baik (berwarna biru).

\section{Tahap pengambilan data \\ Tekanan gas}

Pengukuran gas menggunakan dua alat, yaitu luft meter dan manometer. Luft meter digunakan pada skala laboratorium karena gas yang dihasilkan kecil sedangkan di lapangan menggunakan manometer karena gas yang dihasilkan dalam jumlah banyak tergantung banyaknya kotoran yang digunakan. Tekanan dihitung menggunakan rumus gas ideal berikut:

$\mathrm{Pv}=\mathrm{nRT}$

$\mathrm{Pv}=\frac{\mathrm{m}}{\mathrm{M}} \mathrm{RT}$

Dimana:

$\mathrm{P}=$ tekanan $(\mathrm{atm})$

$\mathrm{v}=$ volume ruang (liter)

$\mathrm{N}=$ jumlah mol gas

$\mathrm{R}=$ tetapan umum gas $(0,082 \mathrm{~L}$ atm $/ \mathrm{mol} \mathrm{K})$

$\mathrm{T}=$ suhu (Kelvin)

$\mathrm{M}=$ Massa relatif atom/molekul

$\mathrm{m}=$ massa zat $(\mathrm{kg})$

Volume gas ditentukan dengan persamaan Boyle-Gay Lusssac, karena terdapat perbedaan suhu, tekanan, dan volume gas pada tabung digester. Persamaannya adalah:

$\frac{\mathrm{P}_{1} \mathrm{~V}_{1}}{\mathrm{~T}_{1}}=\frac{\mathrm{P}_{2} \mathrm{~V}_{2}}{\mathrm{~T}_{2}}$

Dimana:

$\mathrm{P}_{1}=$ tekanan gas pada tabung reactor (atm)

$\mathrm{P}_{2}=$ tekanan gas pada tabung gas $(\mathrm{atm})$

$\mathrm{T}_{1}=$ suhu gas pada tabung reactor $(\mathrm{K})$

$\mathrm{T}_{2}=$ suhu gas pada tabung gas $(\mathrm{K})$
$\mathrm{V}_{1}=$ volume gas pada tabung reactor (liter)

$\mathrm{V}_{2}=$ volume gas tabung gas (liter)

\section{Laju produksi (v, ml/s)}

Laju produksi gas metana menunjukkan kecepatan alat tersebut dalam memproduksi gas yaitu perbandingan antara volume gas yang dihasilkan dengan waktu. $v=\frac{V}{t}$.

Dimana:

$\mathrm{v}=$ laju produksi gas $(\mathrm{ml} / \mathrm{s})$

$\mathrm{V}=$ volume gas $(\mathrm{ml})$

$\mathrm{t}=$ waktu (s)

\section{Pengukuran jumlah molekul gas metan $(\mathbf{N})$}

Setiap sampel kecil gas terdiri dari banyak molekul (N) untuk suatu jenis zat kimia tetentu, semua molekulnya identik. Banyak molekul dihitung dengan rumus berikut:

$\mathrm{N}=\frac{m N}{M} \operatorname{dan} N_{A}=\frac{N}{n}$

Dimana:

$\mathrm{N}=$ Banyak molekul

$\mathrm{M}=$ Massa masing-masing molekul (kg)

$\mathrm{mN}=$ Massa total $(\mathrm{Kg})$

$\mathrm{m}=$ Massa molar $(\mathrm{Kg} / \mathrm{kilomol})$

$\mathrm{n}=$ jumlah mol

Untuk 1 mol gas ideal pada $273^{\circ} \mathrm{K}$ dan pada tekanan atm baku menempati volume $2,24 \times 10^{4} \mathrm{~cm}^{3}$, maka terdapat $3 \times 10^{19}$ molekul dalam volume $1 \mathrm{~cm}^{3}$ dan $3 \times 10^{16}$ molekul $/ \mathrm{mm}^{2}$. Bahkan volume sekecil satu mikrometer kubik berisi $3 \times 10^{7}$ molekul.

\section{Temperatur $\left({ }^{\circ} \mathbf{C}\right)$}

Temperatur dapat diukur dengan menggunakan termodigital dan termometer dengan skala celcius $\left({ }^{\circ} \mathrm{C}\right)$.

\section{Pengukuran BOD (Biological Oxygen Demand)}

Nilai BOD dihitung dengan rumus sebagai berikut:

$\mathrm{BOD}=\left(\mathrm{DO}_{0}-\mathrm{DO}_{5}\right) \times$ Pengenceran

Sedangkan pengukuran produksi gas metana dapat ditentukan dengan persamaan hubungan:

$\mathrm{G}=5,62(\mathrm{eF}-1,42 \mathrm{~A})$ 
Dimana:

BOD = kandungan bahan organik $(\mathrm{mg} / \mathrm{l})$

$\mathrm{DO}_{0}=$ jumlah oksigen pada hari ke- $0(\mathrm{mg} / \mathrm{l})$

$\mathrm{DO}_{5}=$ jumlah oksigen pada hari ke-5 $(\mathrm{mg} / \mathrm{l})$

Pengenceran $=$ Faktor pengenceran sampel

$\mathrm{G}=$ Produksi $\mathrm{CH}_{4}, \mathrm{ft}^{3} /$ day

$\mathrm{e}=$ Efisiensi BOD $(1,32)$

$\mathrm{F}=$ Peningkatan $\mathrm{BOD}, \mathrm{lb} /$ day

A = Total Suspended Solid (TSS), lb/day

(Eckenfelder, 1966)

\section{PengukuranTSS (Total Suspended Solid)}

TSS terdiri dari partikel-partikel yang ukuran maupun beratnya lebih kecil dari sedimen, misalnya tanah liat, bahan-bahan organik tertentu, sel-sel mikroorganisme, dan sebagainya (Nasution, 2008). Persamaannya adalah:

$\operatorname{TSS}(\mathrm{mg} / \mathrm{l})=(\mathrm{A}-\mathrm{B}) \mathrm{X} 1000 / \mathrm{V}$

Dimana:

$\mathrm{A}=$ berat kertas saring sebelum di oven (gr)

$\mathrm{B}=$ berat kertas saring setelah di oven (gr)

$\mathrm{V}=$ volume sampel $(\mathrm{ml})$

\section{Massa jenis $(\rho, \mathrm{gr} / \mathrm{ml})$}

Massa jenis adalah pengukuran massa setiap satuan volume benda. Semakin tinggi massa jenis suatu benda, maka semakin besar pula massa setiap volumenya. Persamaannya adalah:

Massa jenis $=\frac{m}{v}$

Dimana:

$\mathrm{m}=$ massa sampel $(\mathrm{gr})$

$\mathrm{v}=$ volume sampel $(\mathrm{ml})$

Validasi model matematika untuk perancangan

$\%$ ERMS $=\sqrt{\frac{\sum\left(\frac{X \text { SIMULASI-X AKTUAL }}{X \text { XKTUALL }}\right)^{2}}{n}}$ X100\%...9)

Dimana:

$\mathrm{X}$ Simulasi $=$ nilai simulasi

$\mathrm{X}$ Aktual $=$ nilai aktual

$\mathrm{n}=$ jumlah data

\section{Analisis Data}

Data akan dianalisis menggunakan dua pendekatan yaitu pendekatan matematik, yaitu dengan persamaan yang sudah ditentukan dan statistik untuk mengetahui hubungan variabel dengan parameter-parameter menggunakan program excel dan statgraf.

\section{Diagram Alir Penelitian}

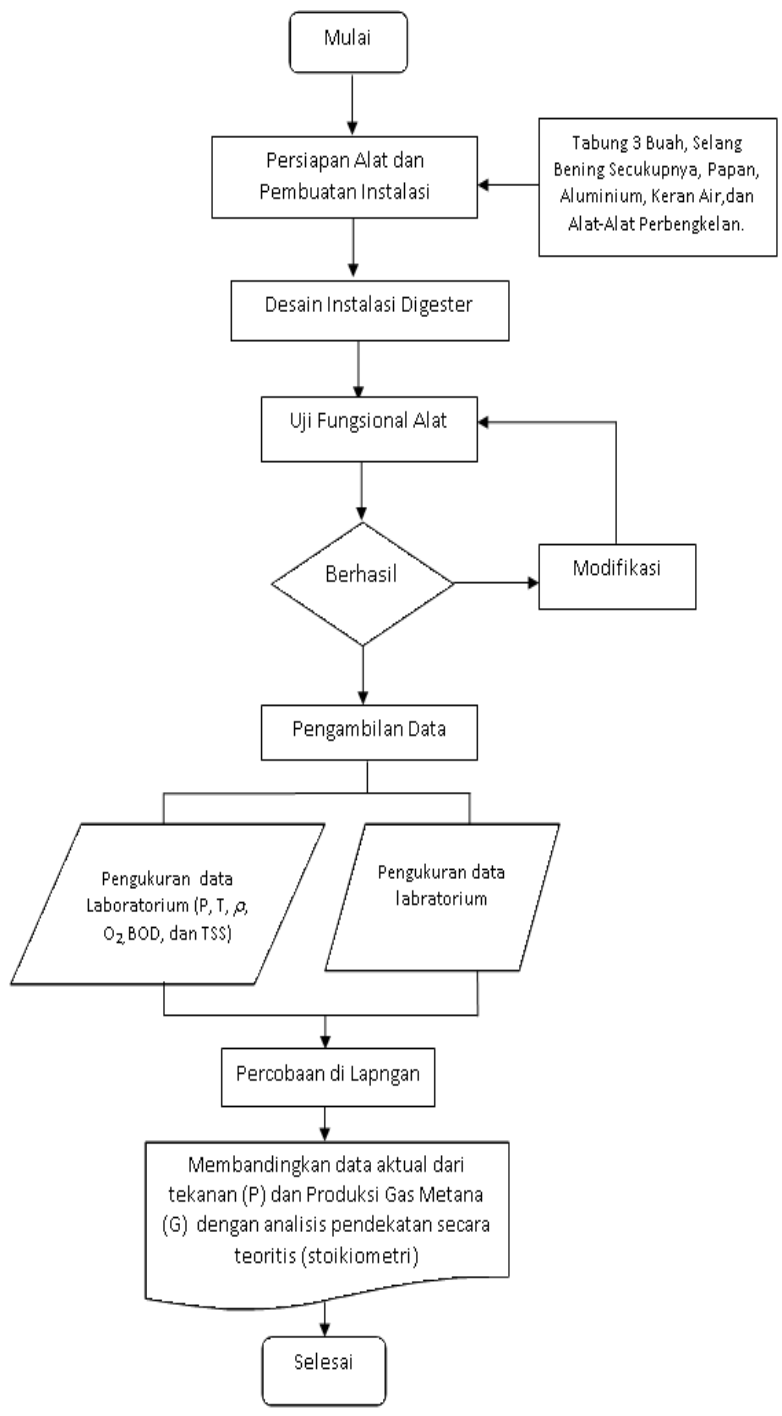

Gambar 1. Diagram alir penelitian

HASIL DAN PEMBAHASAN

\section{Tekanan}

Tekanan dalam reaktor pada penelitian ini diukur secara langsung menggunakan luft meter sehingga dapat diketahui bahwa proses terjadinya reaksi pada reaktor untuk menghasilkan seberapa banyak tekanan yang dihasilkan serta untuk mengetahui peningkatan yang terjadi sampai kandungan gas dalam bahan tersebut habis. Berdasarkan uji pendahuluan, setiap ulangan dilakukan selama 2 hari sampai titik konstan yaitu tidak terjadi peningkatan dalam memproduksi gas metana. 


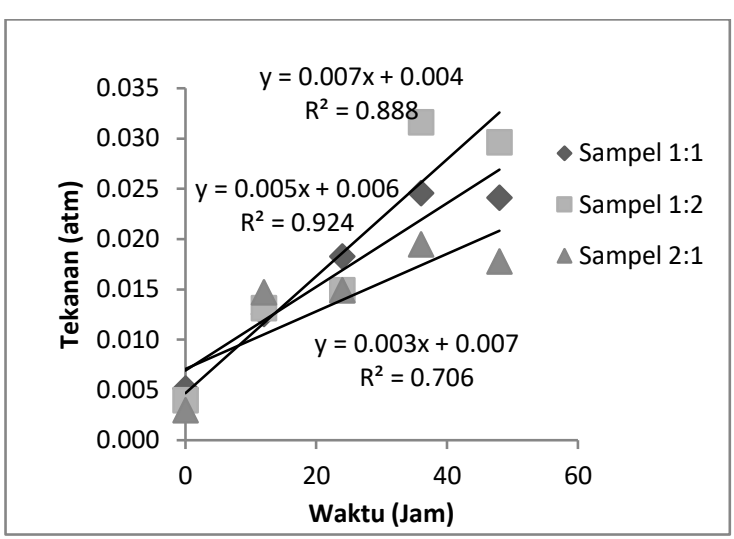

Gambar 2. Grafik perbandingan tekanan

aktual sampel 1:1, 1:2, dan 2:1

Grafik pada gambar 2 menunjukkan perbandingan tekanan aktual tiap sampel. Melihat bentuk gambar tersebut dapat dikatakan bahwa hubungan tekanan terhadap waktu adalah berbanding lurus dengan semakin banyak waktu yang dihabiskan maka tekanan yang dihasilkan akan semakin meningkat dan sebaliknya. Perbandingan masing-masing sampel dilihat dari jumlah tekanan yang dihasilkan, yaitu pada waktu yang sama untuk semua sampel selama terjadinya proses produksi dari jam ke-0 hingga jam ke-36 mengalami peningkatan. Sampel 1:1 menghasilkan tekanan tertinggi 0,0245763 atm pada hari kedua (36 jam), sampel 1:2 0,0315840 atm di jam yang sama, begitu juga dengan sampel 2:1 diproleh tekanan 0,019444 atm. Dari ketiga sampel dapat disimpulkan dengan ukuran bahan yang sama, yaitu $2000 \mathrm{ml}$ dengan komposisi air yang berbeda tekanan tertinggi diperoleh pada sampel 2:1 karena jumlah volume kotoran lebih banyak.

Analisa menggunakan statgraf pada sampel 1:2 dengan persamaan $\mathrm{y}=5.06 \mathrm{x}+1.96$ dan $\mathrm{R}^{2}=0,924$. Output menunjukkan bahwa model linier untuk menggambarkan hubungan antara tekanan dan waktu dengan persamaan tekanan $=7.02+0,421667 *$ terhadap waktu, dan nilai $\mathrm{P}$ pada tabel ANOVA kurang dari 0,01 menunjukkan bahwa adanya hubungan yang signifikan secara statistik antara tekanan dan waktu dengan tingkat kepercayaan 99\%. Sedangkan R-Square secara statistik menunjukkan nilai $92,4144 \%$ dari variabilitas dalam tekanan dengan koefisien korelasi sama dengan 0.961324 menunjukkan adanya hubungan yang kuat pula terhadap variabel relatif dengan standar error dari estimasi yaitu standar deviasi dari residu menjadi 2,64676. Begitu juga dengan sampel 2:1 dan 1:1 karena nilai nilai R-Square 0,888 dan 0,706 memiliki hubungan yang cukup kuat dan berpengaruh nyata terhadap waktu. Sedangkan di bawah ini adalah grafik hasil perhitungan analisa data teoritis gas ideal.

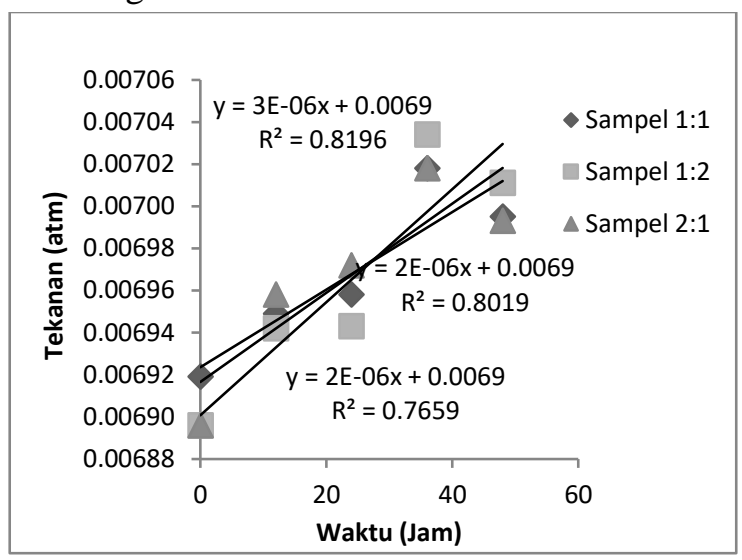

Gambar 3. Grafik perbandingan hasil perhitungan teoritis gas ideal sampel 1:1, 1:2, dan 2:1

Analisa hasil pengukuran secara langsung dibandingkan dengan perhitungan secara teoritis untuk mendukung kebenaran dari data hasil penelitian yang sudah dilakukan. Gambar 3 di atas merupakan grafik hasil perhitungan secara teoritis gas ideal, yaitu melalui pendekatan sesuai dengan referensi yang digunakan. Tekanan selama 48 jam terus meningkat sama seperti data aktual arena gas yang terbentuk selama 2 hari tidak digunakan tapi ditampung untuk mengetahui jumlah tekanan yang dihasilkan. Waktu dengan tekanan yang dihasilkan terlihat berbanding lurus yaitu semakin banyak waktu yang dihabiskan gas yang dihasilkan juga akan meningkat. Berdasarkan penelitian yang dilakukan dengan pengambilan data secara langsung pada laboratorium kandungan gas dalam lumpur yang sudah tercampur rata habis. Dari kedua pendekatan tersebut disimpulkan bahwa tekanan yang dihasilkan baik secara aktual maupun secara teoritis tidak berbeda nyata. 


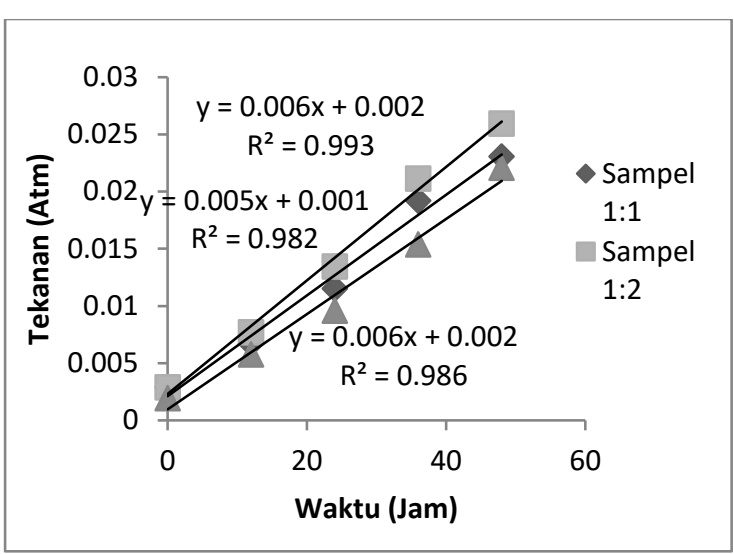

Gambar 4. Grafik perbandingan tekanan data lapangan sampel 1:1, 1:2, dan 2:1

Grafik pada gambar 4 merupakan data perbandingan berdasarkan gas ideal secara aktual di lapangan, dimana tujuan dari pengukuran tersebut untuk membandingkan tekanan yang diproleh di laboratorium. Dari hasil pengukuran tersebut secara aktual di lapangan terlihat sama-sama mengalami peningkatan hingga 48 jam karena gas yang terbentuk ditampung pada manometer dan tidak digunakan selama pengambilan data, berbeda dengan aktual di laboratorium yaitu pada jam 36 hingga 48 mengalami penurunan menunjukkan bahwa kandungan gas dalam bahan sudah habis.

Sampel 1:1 merupakan perbandingan volume yang sama antara air dengan kotoran sapi. Pada sampel ini diperoleh tekanan sebanyak 0,023050 atm pada hari kedua pada jam ke 48, sedangkan sampel 1:2 merupakan sampel dengan perbandingan 2 liter kotoran dengan 1 liter air sehingga dengan perbandingan tersebut menyebabkan campuran menjadi kental dibandingkan dengan sampel yang lain. Dari hasil penelitian yang dilakukan dengan ketiga sampel tersebut dapat disimpulkan bahwa tekanan tertinggi diproleh pada sampel 1:2 yaitu 0,025931 atm dan untuk sampel terakhir yaitu 2:1 merupakan campuran paling encer karena jumlah perbandingan air lebih banyak sehingga tekanan yang dihasilkan juga rendah yaitu 0,022089 atm pada hari kedua, jam ke 48 karena tekanan yang dihasilkan pada skala lapangan diukur menggunakan manometer dan tidak digunakan selama pengambilan data.

\section{Temperatur}

Temperatur pada dasarnya salah satu faktor yang berpengaruh terhadap pembentukan gas metana karena temperatur merupakan konsep termodinamika yang terlibat pada persamaan $\mathrm{PV}=\mathrm{nRT}$. Temperatur biasanya dinyatakan sebagai fungsi dari salah satu koordinat termodinamika. Maka dari itu temperatur yang dimaksud pada penelitian ini adalah temperatur yang ada di dalam tabung reaktor (tempat terbentuknya gas) dan alat yang digunakan untuk mengukur temperatur pada penelitian ini khususnya skala laboratorium adalah termokopel (ruang hampa) sedangkan di lapangan menggunakan termometer batang. Dimana tujuan dari pengukuran temperatur tersebut untuk mengetahui pengaruhnya terhadap gas yang dihasilkan setiap 12 jam. Untuk lebih jelasnya perbandingan temperatur setiap perlakuan dapat dilihat pada grafik berikut ini:

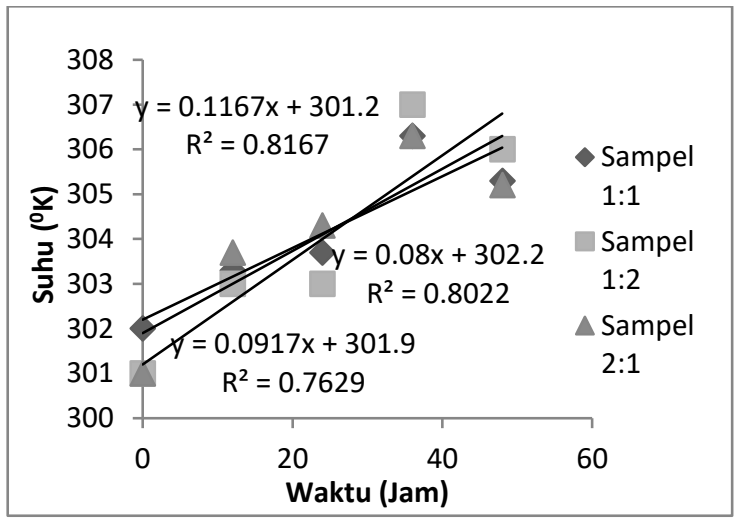

Gambar 5. Perbandingan temperatur laboratorium sampel 1:1, 1:2, dan 2:1

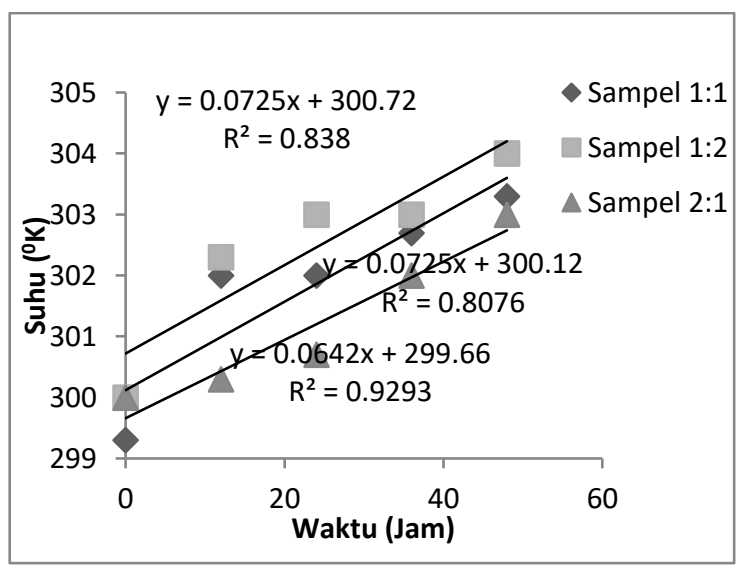

Gambar 6. Perbandingan temperatur lapangan sampel 1:1, 1:2, dan $2: 1$ 
Temperatur merupakan pengaruh utama pembentukan gas metana, jumlah gas yang terkandung dalam bahan akan cepat terbentuk apabila temperatur tinggi dan sebaliknya apabila temperatur pada tabung reaktor rendah maka proses pembentukan gas akan lambat karena temperatur tersebut merupakan energi yang menyebabkan bahan tersebut menjadi panas sehingga kandungan gas dalam bahan akan menguap atau terpisah dengan cepat.

Temperatur lapangan berkisar antara $300-300,7^{\circ} \mathrm{K}$. Kondisi digester khususnya pada tabung reaktor baik di lapangan maupun laboratorium memiliki fungsi yang sama, namun berdasarkan kondisi di lapangan yaitu dengan reaktor sebesar 4 kubik bentuk kubah, selama beberapa hari reaktor harus terisi penuh dengan kotoran dan pada dasarnya menggunakan perbandingan 1:1 sehingga selama pengambilan data untuk sampel 1:2 dan 2:1 didominasi oleh perbandingan 1:1 sehingga hasilnya pun memiliki perbedaan yang tipis pada semua sampel.

\section{Volume dan laju produksi gas metana}

Penentuan volume gas metana $\left(\mathrm{CH}_{4}\right)$ hasil fermentasi dianalisa menggunakan pendekatan teori karena pendekatan secara aktual tidak memungkinkan, mengingat alat ukur volume gas tidak ada. Pendekatan tersebut dilakukan dengan menggunakan persamaan Boyle Gay-Lussac PV $=n R T$. Hal yang menentukan dalam penentuan volume gas adalah tekanan dan temperatur.

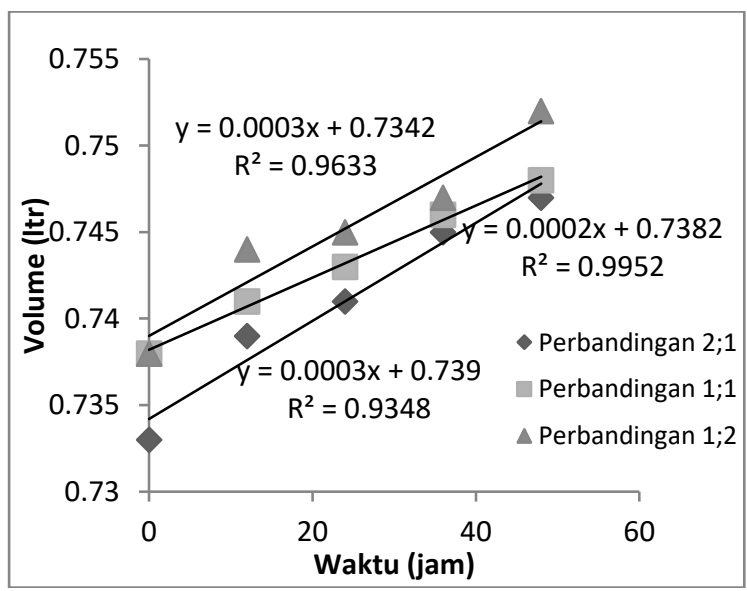

Gambar 7. Grafik perbandingan volume sampel 1:1, 1:2, dan 2:1

Grafik pada gambar 7 menunjukkan hubungan antara waktu dengan volume berbanding lurus, yaitu semakin banyak waktu yang digunakan semakin tinggi volume gas yang dihasilkan. Begitu sebaliknya, semakin sedikit waktu yang digunakan volume gas yang dihasilkan juga sedikit. Dari ketiga sampel tersebut dapat dilihat volume tertinggi ditemukan pada sampel 1:2, yaitu sampel yang paling kental disebabkan karena kandungan gas tergantung pada jumlah bahan atau kotoran yang digunakan selama proses produksi yaitu selama 48 jam.

Sampel 1:1 memiliki volume tertinggi yaitu $0,63881 \mathrm{ml}$ angka ini menunjukkan bahwa pada jam tersebut gas dapat diproduksi secara maksimal. Sampel 1:1 jika dibandingkan dengan sampel 2:1 yaitu sebesar $0,63938 \mathrm{ml}$, dimana sampel tersebut menunjukkan perbedaan yang tidak signifikan karena hampir sama. Sedangkan volume tertinggi ditemukan pada sampel 1:2 jika dibandingkan dengan sampel kedua tersebut, hal ini menunjukkan bahwa perbandingan 1:2 mampu memproduksi gas terbanyak dibandingkan sampel 1:1 dan2:1.

Laju pembentukan gas metana adalah banyaknya gas yang terbentuk dari bahan persatuan waktu. Pada semua perlakuan, laju pembentukan gas metana dengan bahan kotoran sapi berada pada laju meningkat. Laju produksi merupakan kecepatan alat tersebut dalam menghasilkan gas setiap jamnya yaitu perbandingan antara produksi gas metana dibagi waktu selama pembentukan, adapun laju produksi metana masing-masing sampel dapat dilihat pada grafik berikut:

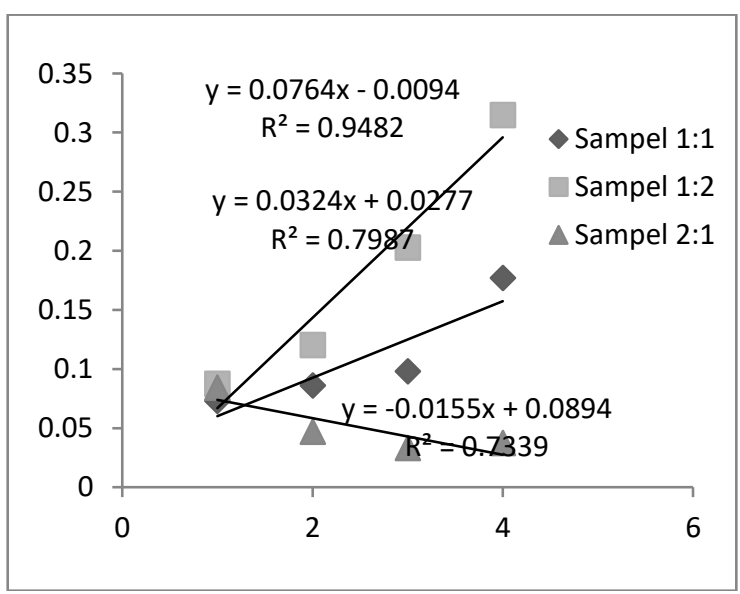

Gambar 8. Grafik laju produksi gas metana sampel 1:1, 1:2, dan 2:1

Grafik pada gambar 8 merupakan laju pembentukan gas metana setiap jam. Sampel 
1:1 dan sampel 1:2 dari hari pertama sampai hari kedua mengalami peningkatan hal ini menunjukkan bahwa pada kedua sampel tersebut tidak terjadi pemecahan secara sempurna setiap jam, menyebabkan masih adanya bahan-bahan yang membutuhkan waktu lebih lama berproduksi atau dengan kata lain mikrobia yang membantu proses perombakan pada pembentuksn gas metana tidak bisa bekerja dengan baik apabila masih berbentuk polimer sehingga perlu penyederhanaan menjadi lebih sederhana, sedangkan pada sampel perlakuan encer (2:1), yaitu berbanding terbalik dengan kedua sampel tersebut, mengalami penurunan karena terjadinya proses secara sempurna.

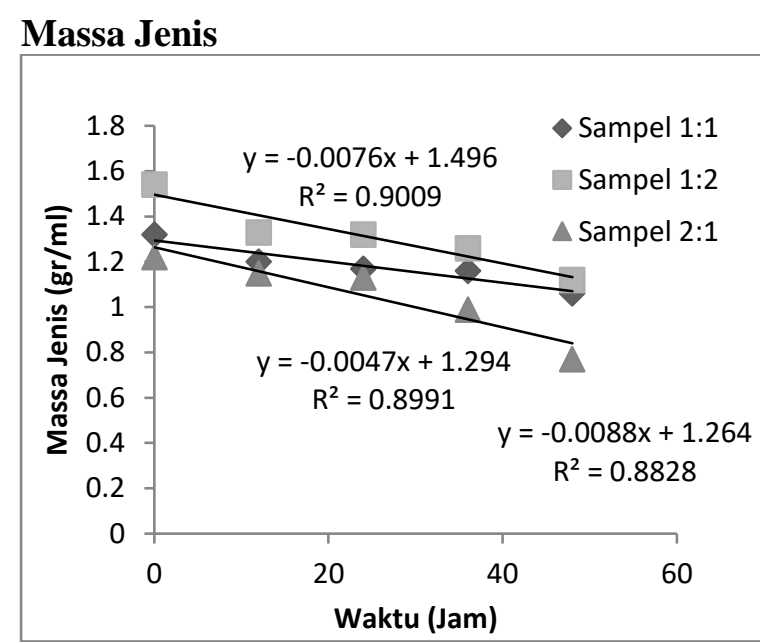

Gambar 9. Grafik hubungan massa jenis terhadap produksi gas metana

Dilihat dari grafik pada gambar 9, selama proses fermentasi massa jenis bahan semakin lama semakin menurun. Massa jenis tertinggi adalah 1:2 (satu liter air dengan dua liter kotoran) jadi larutan ini berdasarkan dari tingkat kekentalan merupakan larutan yang paling kental karena pencampuran kotoran lebih banyak, untuk massa jenisnya nilai terendah $1,12 \mathrm{gr} / \mathrm{ml}$ dan nilai tertinggi mencapai $1,54 \mathrm{gr} / \mathrm{ml}$ pada volume $5 \mathrm{ml}$ pada hari sebelum kotoran dimasukkan ke dalam tabung reaktor.

Begitu juga dengan perbandingan 1:1 dan 2:1 dari hasil di atas komposisi air juga mempengaruhi massa jenis suatu bahan, semakin encer, maka massa jenisnya juga semakin rendah namun kondisi di dalam reaktor juga sangat mempengaruhi karena dilihat dari nilainya semakin hari massa jenis juga semakin menurun hal ini menunjukkan dengan terambilnya gas yang ada di dalam bahan tersebut menyebabkan massa jenisnya berkurang.

\section{Produksi Gas metana}

Berdasarkan hasil perhitungan produksi gas metana pada masing-masing perlakuan dapat dilihat pada gambar berikut:

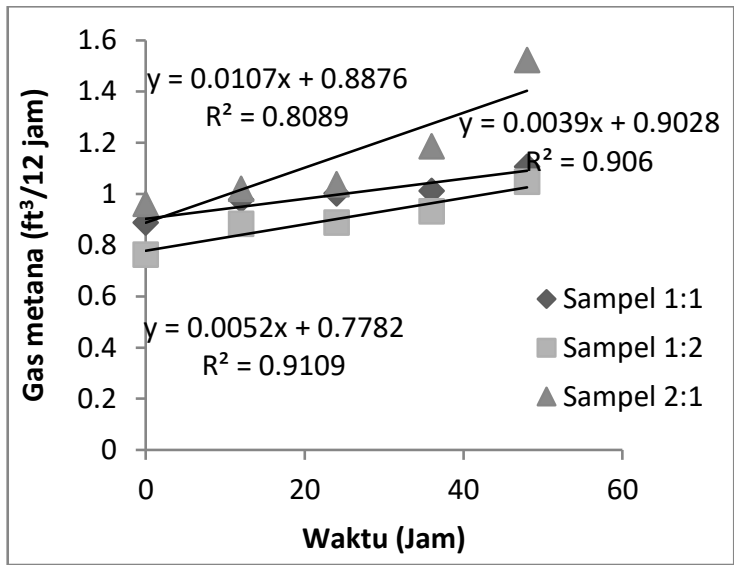

Gambar 10. Grafik perbandingan nilai aktual produksi gas metana pada sampel 1:1, 1:2, dan 2:1

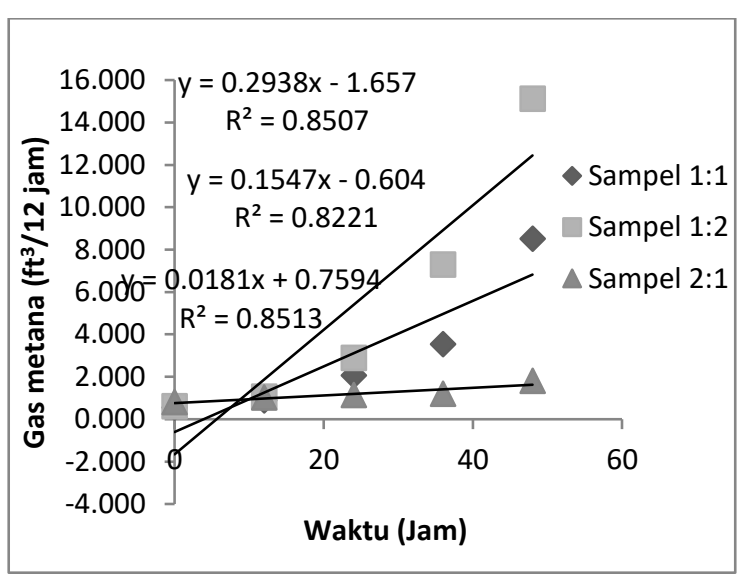

Gambar 11. Grafik perbandingan nilai teoritis (stoikiometri) produksi gas metana pada sampel 1:1, 1:2, dan 2:1.

Grafik pada gambar 10 dan 11 merupakan perbandingan jumlah gas metana yang dihasilkan pada setiap sampel secara aktual dan berdasarkan stoikiometri. Pada penelitian ini divariasikannya perbandingan volume air dengan volume kotoran bertujuan untuk melihat pada perbandingan volume yang mana produksi gas metana berproduksi dengan baik. Hasil analisa baik secara aktual maupun secara teoritis dari ketiga sampel tersebut, yaitu dengan perbandingan volume air yang 
berbeda memiliki menunjukkan produksi gas metana yang berbeda.

Peranan air dalam memproduksi gas metana sangat penting karena membantu proses penguraian oleh bakteri, sehingga terjadi proses anaerobik secara sempurna menyebabkan terbentuknya gas. Hal ini selaras dengan hasil penelitian Wahyudi (2013), bahwa penambahan kadar air sebanyak $16,7 \%$ pada campuran eceng gondok dan feses sapi dapat meningkatkan kadar metana sebanyak 20,25\%. Dari ketiga sampel di atas berdasarkan anlisa secara aktual dan teoritis tidak valid pada perbandingan 1:2 dan 1:1 karena memiliki nilai \% ERMS di atas $10 \%$ dan diperoleh perbandingan volume terbaik, yaitu pada sampel 2:1 (perbandingan 2 liter air dengan 1 liter kotoran) dengan nilai \% ERMS kurang dari $10 \%$ yaitu $9,21 \%$ menunjukkan bahwa data tersebut valid.

\section{KESIMPULAN DAN SARAN}

\section{Kesimpulan}

Berdasarkan hasil analisa dan pembahasan, dapat ditarik beberapa kesimpulan sebagai berikut:

1. Rancangan digester pembuatan gas metana terdiri dari tabung reaktor, penampungan gas metana, keran sebagai penutup dan selang sebagai penyalur gas.

2. Dalam memproduksi gas metana hal-hal yang berpengaruh adalah temperatur dalam tabung reaktor, karena apabila temperatur rendah maka akan semakin lama waktu yang dibutuhkan untuk memproduksi gas metana.

3. Dengan komposisi air yang berbeda ditemukan bahwa perbandingan air merupakan faktor penting dalam memproduksi gas metana karena berpengaruh terhadap bakteri yang bekerja dalam pembentukan gas metana. Berdasarkan penelitian yang dilakukan nilai \% ERMS di bawah 10\% ditemukan pada sampel 2:1.

4. Dari kedua pendekatan yang digunakan secara aktual dan berdasarkan teori gas ideal tekanan yang dihasilkan tidak jauh berbeda.

5. Berdasarkan hasil analisis membuktikan keterkaitan antara laju produksi gas metana secara eksperimental dengan stoikiometri, ditemukan pada perlakuan campuran kotoran sapi dengan air pada kondisi encer atau perbandingan 2:1.

\section{Saran}

Adapun saran yang disampaikan pada penelitian ini sebagai berikut:

1. Untuk peneliti selanjutnya, dalam peningkatan efisiensi alat, dapat memodifikasi jenis dan bentuk reaktor, karena hal tersebut merupakan bagian terpenting dalam instalasi digester dalam memproduksi gas metana.

2. Dapat digunakan penelitian selanjutnya dengan melakukan penelitian serupa tetapi menggunakan bahan atau perlakuan yang berbeda.

\section{DAFTAR PUSTAKA}

Eckenfelder, Wisley W. 1966. Industrial Waster Pollutan Control. Mc Graw Hill.

Hozairi, Bakir, Bukhari. 2012. Pemanfataan Kotoran Hewan menjadi Energi Biogas untuk Mendukung Pertumbuhan UMKM di Kabupaten Pamekasan. Universitas Islam Madura. Madura.

Marsono. 2008. Superkarbon Bahan Bakar Alternatif Pengganti Minyak Tanah dan Gas. Penebar swadaya. Jakarta.

Nasution, AH. 2008. Perencanaan dan Pengendalian Produksi. Yogyakarta: Graha Ilmu.

Rahayu, Sugi. 2008. Pemanfaatan Kotoran Ternak Sapi Sebagai Sumber Energi Alternatif Ramah Lingkungan Beserta Aspek Sosio Kulturalnya. http://www.petra.ac.id/science/applied technology/biogas 98/biogas.html (Diakses 18 Desember 2013).

Wahyudi, A., Iskandar R. 2013. Pengaruh Komposisi Air dalam Pembentukan Biogas dari Enceng Gondok Waduk X Koto Padang Panjang dan Feses Sapi. Repository Universitas Andalas. Padang. 
Wahyuni, Sri. 2009. Menghasilkan Biogas Dari Aneka Limbah. Jakarta: PT

Agromedia Pustaka.

http://srielfyra.blogspot.com /2012/10/makalah-pemanfaatankotoran sapi.html (Diakses 18 Desember 2016) 